\title{
FARM SUPPLY RESPONSE TO PRICE: A CASE STUDY OF SUGARCANE IN PAKISTAN (1986 - 2005)
}

\author{
Raza Ali khan and S.M. Ahsan Hussain \\ SZABIST \\ Karachi, Pakistan
}

\begin{abstract}
Abstrac Sugar cane is one of the most important agricultural outputs of Pakistan and has been termed as a cash crop by the Economic experts. It is mainly grown for sugar and sugary production. It is an important source of income and employment for the farming community of the country. The growing importance of sugarcane in the economy of Pakistan and the policy implications that could follow changes in relative prices have encouraged the under taking of this study. It is therefore proposed to investigate and observe in this paper how the farmer acreage responds to price change in Pakistan during the period of 1986 - 2005, insofar as sugarcane cultivation is concerned.

The main objective of this study is to present and analyze the price elasticity of sugarcane acreage in Pakistan. This study aims to find the acreage response of farmers to price changes in order to make it comparable with standard analysis.
\end{abstract}

\section{INTRODUCTION:}

Agriculture plays an important role in economic development of any economy and Pakistan is no exceptions in this regard. In the Pakistan economy the most important source of livelihood is the agricultural sector. Pakistan economy has under gone considerable diversification over the years, yet the agriculture sector is still largest sector of the economy. With the present contribution to GDP at $23.3 \%$ it accounts for $42.1 \%$ of the total employed labour force and is the largest source of foreign exchange earning $s$ by serving as the base sector for the country's major industries like textile and sugar [1]. What is important from industrialization point of view is the generation of marketable surplus. According to Maurice Dobb "there is a reason to suppose that it will be the marketed surplus of agriculture, which plays the crucial role in underdeveloped countries in setting the limits to the possible rate of industrialization". It is to be noted, "Industrial progress cannot be achieved, without agricultural advancement and progress, unless we are self-sufficient in agriculture, we cannot have the where-withal to advance in industries”. Price plays an important role in the selection of crops and generation of marketed surplus. Generally higher prices are expected to result in a larger output. Prices are therefore, among the most important determinants of the area under different crops. In this study an attempt has been made to examine the acreage response of sugarcane in Pakistan to change in its relative price.

\subsection{Literature Review:}

In economic analysis of the farm supply response, price is considered to be the critical economic factor that determines farmer's production decisions [2].

The extant to, which farmers in under developed areas respond to price change in a widely debated subject. To date however most discussion have been speculative in nature, and have been based a priori consideration of peasant behavior and institutional limitation. Though few authors have argued that farmers in poor countries respond positively to price and income incentives, the majority appear believe in negative or zero price elasticity of supply [3]. Generally, higher prices are expected to result in a larger cultivation of area under sugar cane. If this were to be true, why have agricultural prices in Pakistan and other less developed countries too failed to enthuse the production sufficiently? Have agricultural prices no impact on agricultural growth, which is the essential pre-requisite for economic development of less developed countries.

To formulate and analyze our problem and better understanding of subject, I would like to discus here few important studies, which have been under taken to observe the allocative nature of prices and supply response in Pakistan as well as to other regions on Sugarcane crop and other crops.

\section{Marc Nerlove :}

His paper deal with the role that Farmer's expectations of future relative price s play in shaping their decisions as to how many acres devote to each crop. He derived expressions for the acreage response to relative prices, which he termed as supply functions of cotton, wheat and corn for the United States in the pre war period (1909-32). Nerlove suggested on "adjustment" model as against the "expectation" models suggested by many others including R.L Kohls, Bradford Smith, Louis Bean, Robert Walsh and Don Paarlberg. All these studies suggested that farmers respond very little to price in planning their acreage. All of them, more or less, assume that "farmer react, not to last year's price, but rather to price they expect and this expected price depends only to limited extent on what last year's price was"[4].

\section{Raj. Krishna}

He presented some estimates of the short run and long run elasticities of supply of agricultural commodities derived from the series data for Punjab during the pre war period (1913-14 to 1945-46). He made use of Neriovian adjustment type model. He proposed, "Acreage planted" as the dependent variable and not the 
output. Kirshna suggested the elasticity of planned output with respect to price to be at least equal to the elasticity of acreage planted on the assumption that inputs other than land are varied in proportion to acreage and that returns to scale are not diminishing.

He tested his hypothesis for eleven commodities including sugarcane and his analysis reveals that Jawar is only crop, which possibly has negative response to relative price movements; all other crops have positive short run and long run elasticity's [5]

\section{K.Subbaro :}

He examined the acreage and output response of sugarcane in Andhra Pardesh to changes in relative price during1952-65. He estimated price elasticities of acreage output and yield deflated by the competing crop price. Subbaro concluded that change in relative acreage under sugarcane is positively associated with change in its relative price [6].

\section{Asif Masoood and Malik Anver Javed :}

Their analysis revealed that highly significant results for procurement price, lagged sugarcane area and water availability at farm gate during the crop growth period. Sugarcane area and yield forecast models are very efficient and can be used to predict future area and yield estimates with reasonable level of accuracy a couple of months before sowing and harvesting of sugarcane crop [7] .

Unfortunately, with regard to the supply response of sugar cane in Pakistan only a few studies are undertaken for different time periods. In this study an attempt has been made to examine the acreage response of sugarcane in Pakistan to change in its relative price. Research on sugar-cane supply response is relevant in the present context of its crisis, because sugar-cane is one of the important commercial crops and growers in the sugarcane industry have been struggling under financial pressure for several years [8].

\section{RESEARCH PROBLEM:}

There are many factors that have been responsible for affecting the supply of sugarcane and acreage response of farmer like price of sugarcane, price of other competing products, pests, disease and weeds, sterilized seeds, fertilizer, availability of water and availability of credit cash etc.

In this study we shall limit our concentration on the acreage response of sugarcane production in Pakistan to change in its relative price. This study aims to find the acreage response of farmers to price changes in order to make it comparable with standard analysis.

Journal of Independent Studies and Research (JISR) Volume 5, Number2, July 2007

\subsection{Research Hypothesis}

This proposed study aims at testing the hypothesis that "Farmer of sugarcane in Pakistan do not respond, respond insignificantly or negatively to the relative change in price”.

\section{RESEARCH METHODOLOGY:}

A simple statistical and econometric analysis will be used to know the general properties of data and to see the relationship among variables of interest like Support price of sugarcane, yield of sugarcane, acreage under sugarcane and water availability for sugarcane crop. The multiple regression (Ordinary Least Squares) analysis was employed for sugarcane area and yield forecast model.

Different explanatory variables were explored before settling down for the ones which could give best result in terms of economic logic and satisfy certain statistical criteria.

\subsection{Data Collection:}

It is a time series analysis and is intended to cover the period 1985-86 to 2003-04. The year1985-86 is taken as base period of study. Because it is the year in which the farmers were encouraged to cultivate cash crops such as Sugar cane due to prevalence of high prices.

The year 2003-04 was chosen as the end period of the study because it the published data on which this study is based is available up to 2003-04 when this problem was taken up for study. The study is based on the secondary data collected from the reports published by the Federal Bureau of Statistics, Statistic Division Government of Pakistan, Ministry of Food, Agriculture \& Livestock (Economic Wing) Islamabad and State Bank of Pakistan. The main purpose of using secondary data was to save time and getting quick information about forecasting.

\subsection{Techniques used:}

The present study adopts multiple regression technique of Partial adjustment model. The form of which is as under

$Y_{t}^{*}=a+b X_{t}$

Indicate the Optimal value of “ $Y$ " associated with $X_{t}$. The final equation of the model can be obtained as follows

$$
Y_{t}-Y_{t-1}=\gamma\left[Y_{t}^{*}-Y_{t-1}\right] \quad(0 \leq \gamma \leq 1)
$$

Above equation stated the reaction or adjustment function that implies the individual would probably move only part of the way $(\gamma \leq 1)$ from his starting position ( $\left.\mathrm{Y}_{\mathrm{t}-1}\right)$ to the optimal position $\left(Y_{t}^{*}\right)$.

$Y_{t}=\gamma Y_{t}^{*}-\gamma Y_{t-1}+Y_{t-1}+u_{t}$

For period $t-1$, the same equation can be written as:

$Y_{t-1}=\gamma Y_{t-1}^{*}-\gamma Y_{t-2}+Y_{t-2}+u_{t-1}$ 
Substituting this for the value of $Y_{t-1}$ above, and simplifying, we get:

$Y_{t}=-\gamma^{2} a+\gamma b X_{t}+\gamma(1-\gamma) b X_{t-1}+(1-\gamma)^{2} Y_{t-2}+v_{t}$

For estimation purpose, we write the above equation as follows:

$Y_{t}=A_{0}+A_{1} X_{t}+A_{2} X_{t-1}+A_{3} Y_{t-1}+v_{t}$

Final equation for the Model.

Where

$\mathrm{Y}_{\mathrm{t}}=$ Acreage Under Sugarcane.

$\mathrm{X}_{\mathrm{t}}=$ Procurement Price of Sugarcane.

$\mathrm{Y}_{\mathrm{t}-1}=$ Lagged Acreage Under Sugarcane.

$\mathrm{v}_{\mathrm{t}}=$ Residual Term.

The parameters of the original and the reduced form models are related according to the relations:

$$
A_{0}=-\gamma^{2} a, \quad A_{1}=\gamma b, \quad A_{2}=\gamma(1-\gamma) b
$$

and $A_{3}=(1-\gamma)^{2}$. The last of these relations can be used to determine the value of the adjustment factor $\gamma$. The first three relations can then be used to identify the original values of coefficients of regressors.

The coefficient of adjustment $\gamma$ is the square of one minus the coefficient of lagged dependent variable $\mathrm{i}-\mathrm{e}$ $Y_{t-1}$. Its value usually lies between zero and one $0<\gamma<1$. Implicit meaning of $(0<\gamma<1)$ is that, farmers are able to change the acreage of a crop in any year only to the extent of fraction " $\gamma$ ” i.e., difference between the acreage they would like to plant and the acreage actually planted in the preceding year " $\gamma$ " therefore is an indication of how fast the farmers are adjusting to their expectations. The value of " $\gamma$ " close to unity indicates that the adjustment process is very fast. When the value of " $\gamma$ " is close to zero the implication is that the adjustment process is very slow to the changing prices and other non-prices factors. If the value of " $\gamma$ " is close to one it would mean that the farmers over adjust to the planned acreage.

\section{Table - 1 Regression Results}

Dependent Variable: LOG(SC_AREA)

Method: Least Squares

Date: 05/07/06 Time: 18:08

Included observations: 16 after adjusting endpoints White Heteroskedasticity-Consistent Standard Errors Covariance

\begin{tabular}{lll}
\hline \hline Variable & $\begin{array}{l}\text { Coeffici Std. Error } \\
\text { ent }\end{array}$
\end{tabular}

\begin{tabular}{lllll}
\hline \hline C & 4.7780 & 0.7492 & 6.3773 & 5.2422 \\
LOG(SC_YIEL & 0.4404 & 0.1440 & 3.0570 & 0.01090
\end{tabular}

D)

Journal of Independent Studies and Research (JISR)

Volume 5, Number2, July 2007 $\begin{array}{llll}\text { LOG(SC_SUPP) } 0.1531 & 0.0572 & 2.6732 & 0.02166\end{array}$

$\begin{array}{llll}\text { LOG(SC_AREA }-0.4502 & 0.1929 & -2.3333 & 0.0396\end{array}$

$(-2))$

$\begin{array}{lllll}\text { LOG(WATER) } & 0.5202 & 0.2377 & 2.1882 & 0.0511\end{array}$

\begin{tabular}{|c|c|c|c|}
\hline R-squared & 0.8676 & Mean dependent var & 6.8667 \\
\hline $\begin{array}{l}\text { Adjusted R- } \\
\text { squared }\end{array}$ & 0.8194 & S.D. dependent var & 0.0916 \\
\hline $\begin{array}{l}\text { S.E. of } \\
\text { regression }\end{array}$ & 0.0389 & Akaike info criterion & -3.4039 \\
\hline $\begin{array}{l}\text { Sum squared } \\
\text { resid }\end{array}$ & 0.0166 & Schwarz criterion & -3.1625 \\
\hline Log likelihood & 32.2319 & F-statistic & 18.0232 \\
\hline Durbin-Watson & 1.7929 & Prob(F-statistic) & 8.5383 \\
\hline
\end{tabular}

\section{RESULTS AND DISCUSSION}

We tried many combinations of regressors that included the current and lagged values of the independent variables along with the first and second lag of the dependent variable. The best model was chosen on the basis of the values of adjusted R-square and the value of the Log likelihood. The above table reports the best model out of the many estimated equations for explaining acreage under sugar cane. We find that the levels of yield per hectare, the support price of sugar cane and the level of water availability are the most significant variables that explain the dependent variable. The results of acreage under sugarcane forecast models were studied considering their statistical properties and economic logic. The statistical properties are the coefficient of determination (R2), statistical significance of coefficients, Durban-Watson and F- Statistic. For a statistical model it was considered that economic logic prevails which means that the signs of coefficients are logical and consistent.

\subsection{Acreage under Sugarcane Forecast Model}

Sugarcane area fluctuations are caused by a number of factors. Some of the most important factors are prices of sugarcane, gur, competing crops, availability of water, yield and fertilizers etc. An explanatory variable of acreage under sugarcane was used on lag basis because farmers make crop acreage allocation decision on the basis of past experience. A lagged variable is an observation from a variable recorded from an earlier time period. Before fitting the models, it is very important to carefully identify these variables which will be used in the model. Keeping this viewpoint many explanatory variables were identified (i.e. acreage under sugarcane lagged by 2 years, yield of sugarcane, procurement price, prices of competing crops (cotton), water availability,). Acreage under sugarcane was considered as dependent variable in Acreage under sugarcane forecast model. For the selection of model variables, each independent variable was plotted against dependent variable and their behavior was studied. The variables which had linear relationship were kept while others were dropped. The variables included in the acreage under sugarcane model are sugarcane Yield, 
acreage under sugarcane lagged by two years, sugarcane procurement price and water availability. It is rational to consider procurement price of sugarcane crop and water availability as the major incentive which motivates the farmers to increase area under sugarcane. The model is satisfactory with statistical properties i.e. high R2, appropriate value of Durbin-Watson Statistic and significant F-Statistic, table 1).

For direct estimation of elasticities, all variables have been measured in natural logarithm units. Results indicate that the short term elasticities of yield per hectare, support price and water availability are respectively $44 \%, 15 \%$ and $52 \%$, while the same long run elasticities are higher than the short run values. The figures are reported in the table below. All variables are significant at the $5 \%$ level. The overall F-statistic is also highly significant. This shows that despite the variables having a high correlation with each other, we do not have the multicollinearity problem in our estimates. The Durbin Watson statististic also indicates the absence of autocorrelation among the variables.

\begin{tabular}{lcc}
\multicolumn{2}{l}{ Table - 2. Short Run and Long Run Elasticities } \\
$\begin{array}{l}\text { Variable } \\
\text { Yield per }\end{array}$ & SR elasticity & LR elasticity \\
Hectare & $44.05 \%$ & $55.25 \%$ \\
$\begin{array}{l}\text { Support Price } \\
\text { Water }\end{array}$ & $15.31 \%$ & $19.20 \%$ \\
Availability & $52.02 \%$ & $65.25 \%$
\end{tabular}

The value of $\gamma$ has been estimated to be $79.72 \%$ which is a significantly high speed of adjustment and implies that farmers are able to incorporate the available information in their decision within a time span of one and a half year. This also justifies the use of the second lag of the dependent variable in the estimation equation.

\section{CONCLUSION AND RECOMMENDATIONS}

In the light of above discussion and study results we are unable to accept the presented hypothesis. Study results clearly reject the hypothesis "Peasants in a developing country like Pakistan do not respond, respond insignificantly or negatively to the relative changes in price”. In fact farmers do respond; respond positively and significantly to the changes in relative prices. Prices have been very much effective in the acreage decision taken by farmers. Thus, price-acreage relationship is positive. This means that if the price is enhanced, the production of sugarcane might improve considerably.

It has already been shown that the explanatory power of equation and model have been generally very high, coefficients are highly significant. Autocorrelation and multicollinearity are found absent.

In short it can be said that since price changes influence the farmer's decision about acreage , price can be used as an instrument by policy makers to effect changes in the area under sugarcane and hence the output. Support price program and subsidies to farmers may induce them to increase their production of sugarcane, resulting into substantial surplus in the economy, which may even lead to additional foreign exchange earning.

\section{REFERENCES}

[1] Pakistan Government of [2004] Economic Survey 2003-04, Islamabad.

[2] M. RAMULU, 1996 "Supply Response of Sugarcane in Andhra Pradesh" 116 Finance India FINANCE INDIA Vol. X No. 1, March 1996 Pages - 116-122

[3] Falcon.W.P, "Farmer Response to Price in a Subsistence Economy: The Case of West Pakistan”American Economic Review, Vol. 54, No. 3, 1964

[4] Nerlove,M “ Estimate elasticities of supplyof selected Agricultural, commodities” Journal of Farm Economics, Vol. XXXVIII, No. 2, 1965.

[5] Krishna. R, (1963), "Farm Supply Response in India-Pakistan”, Economic Journal, Vol. LXXII, O.291,

[6] K. Subbaro, “ Farm Supply Response: A case Study of Sugarcane in Andhara Pardesh”, Indian Journal of Agricultural Economics, Vol. XXIV, No. 1.1969 .

[7] Masood.A \& Anwar.M, (2004), "FORECAST MODELS FOR SUGARCANE IN PAKISTAN”, Pak. J. Agri. Sci., Vol. 41(1-2),.

[8] Windle.J \& Rolfe.J, (2005), “Diversi. Cation Choices in Agriculture: A Choice Modelling Case Study of Sugarcane Growers", The Australian Journal of Agricultural and Resource Economics, 49, 63-74. 